Melanie Ellis

Educational Research Institute, Warsaw

\title{
BELIEFS AND ATTITUDES ABOUT LANGUAGE LEARNING AND TEACHING AMONG LEARNERS IN LOWER SECONDARY SCHOOL IN POLAND
}

\author{
Postawy uczniów szkół gimnazjalnych w Polsce wobec \\ uczenia się języków obcych
}

\begin{abstract}
Artykuł omawia założenia i metodologię badań, przeprowadzonych na reprezentatywnej próbie w szkołach gimnazjalnych w Polsce, których celem było opisanie postaw i poglądów na temat uczenia się i nauczania języków obcych w szkołach. Niezbędne do przeprowadzenia analizy dane zostały zebrane za pomocą kwestionariusza, w którym około 4000 respondentów wyraziło swoje opinie, dotyczące 60 zagadnień, w pięciostopniowej skali Likerta. Niniejszy artykuł prezentuje wybrane wyniki badań.
\end{abstract}

\section{Introduction}

This article describes one part of a large study on teaching and learning foreign language in lower secondary schools in Poland which is being conducted on a representative sample of 120 schools across the country. The focus of this part of the study is on the beliefs of young learners, aged 13-14, in the first class of gimnazjum, (lower secondary school), about the learning and teaching of foreign languages, with a particular focus on English. The research project, named BUNJO (Badania uczenia sie i nauczania języków obcych), is a longitudinal study which traces the development of groups of learners through the three years of lower secondary, collecting data by means of tests, questionnaires, interviews and observations, with the aim of building a description, supported by empirical evidence, of how language learning and teaching takes place at this stage of education. 
The part of the study described here was based on a questionnaire, completed by 4343 learners who started learning English in primary school and are now following a continuation program.

\section{Beliefs about learning a foreign language}

The notion of beliefs about learning, and language learning in particular, has been defined in many different ways by different researchers. Beliefs can be seen as metacognitive knowledge about what language is and about how learning takes place (Wenden, 1986; Abraham and Vann, 1987). Other researchers place beliefs within a wider context, stressing that they arise from social and cultural contact (Gardner, 1985; Barcelos, 1995).

For this article the definition which will be adopted is that of Victori and Lockhart (1995: 224) who describe beliefs as: "general assumptions that students hold about themselves as learners, about factors influencing language learning, and about the nature of language learning and teaching".

From a cognitive psychological perspective, the beliefs we hold are viewed as a driving force which influence how and why we act (Flavell, 1987; Ryan, 1984). Within foreign language learning what the learner believes about what learning a foreign language means will have a strong impact on how they go about trying to learn. If, for example, the learner believes that learning a language means learning rules of grammar and patterns of structures this is, theoretically, how they would choose to learn. One problem, of course, is that holding a belief does not necessarily mean that one puts it into action. We can have strong beliefs about what constitutes a healthy diet, for example, but circumstances and other influences may mean we behave differently when faced with a piece of appetizing chocolate cake. We will return to this question in the discussion of research methodology.

It is thought that a learner's beliefs about language learning may be one of the factors which may contribute to individual difference in learning outcomes, although research evidence is scant and inconclusive. Abraham and Vann (1987), in a case study of two learners, found they had different learning outcomes which may have resulted from the learners' different beliefs on what was important in language learning. The learner who felt that conscious attention to grammatical form was more important got better results on a written test than his peer who did not enjoy learning about language and preferred to practice, for example. Park (1995), in a study of 332 university students in Korea, investigating beliefs connected with self-efficacy and 
use of language for communication in interaction, found that those who professed confidence in English and an intention to use English to communicate, in fact used English outside class, monitored their language use carefully and got better results. Mori (1999), researching 187 university students studying Japanese in the USA, found a correlation between those who said they thought language learning was easy and higher achievement; while those who thought language learning was an ability which a learner has or does not have and which could not be changed by effort tended to have lower results. Tanaka and Ellis (2003), reporting on a comparison between Japanese university learners of English on a study visit to New Zealand and a control group in Japan, found that although the New Zealand group's beliefs about language learning changed during the visit, particularly regarding the role of grammar, the correlations between the results on the beliefs questionnaire and a proficiency test were weak. Ellis (2008: 13) concludes: "If beliefs do impact on learning it is likely that they do so indirectly by influencing the kinds of learning strategies learners employ".

Gardner (2006: 240), in his Socio-educational Model of Second Language Acquisition, sees beliefs as playing an important role in learner motivation.

Individual differences in motivation are influenced and supported by factors originating in environmental characteristics (i.e. cultural, personal, social, educational etc.) That is, beliefs in the community, life experiences, and educational objectives and experiences account for differences in motivation. Individual differences in ability, may also develop in part as a consequence of environmental characteristics, but there is probably a large genetic component as well.

Thus a study of beliefs about language learning can be considered of value, as it can inform us of reasons why learners choose to learn in a certain way, may give an insight into learner achievement and throw light on their motivation. Barcelos (2003), in a review of studies on beliefs and language learning, divides research done into three types: normative, metacognitive and contextual, based on the approach taken by the researcher and the methodology applied. In the first category, the work of Horwitz (1987) and research inspired by her study predominate. Horwitz devised a questionnaire, the Beliefs about Language Learning Inventory (BALLI), with the intention of investigating the beliefs of teachers and their learners, on the understanding that if a teacher knows more about their learner's beliefs on how a foreign language is learnt they will be better able to match their teaching style and to choose materials appropriate for that individual. BALLI consisted of 34 items with a five point Likert scale divided into several topic areas including beliefs 
about the nature of foreign language learning, its perceived difficulty and beliefs about learning and communication (Horwitz, 1999: 560). Studies in the BALLI tradition are descriptive and the methodology uses preconceived ideas of what learners are expected to believe about language learning. The studies are largely decontextualised and concern beliefs about language learning in general. This approach has subsequently been criticized as not necessarily tapping what learners in fact believe, as the methodology does not offer them the chance to freely express their thoughts or 'metacognitive knowledge' (Wenden, 1987). Another drawback is that the same statement in a questionnaire may been understood in different ways by different people. The underlying suggestion is that having certain types of beliefs will be associated with success in language learning, thus implicitly assuming a cause/effect relationship. However, as was noted earlier, no account is made for the fact that learners may act quite differently from the beliefs they profess to hold.

Studies in the metacognitive category are also of a cause and effect nature but overcome the limitations of the questionnaire based study by examining 'theories in action' during structured interviews (Wenden, 1999). Contextual studies, the third category, aim to understand the beliefs of specific learners in a chosen context and use a variety of methods of data collection, such as classroom observation, interviews and metaphor analysis, to take into account the interaction with the social situation. In this approach it is thought that beliefs are dynamic and may change over time and as a result of interaction with the environment in which the learning takes place (Barcelos, 2003: 26).

\section{Attitudes to the learning situation}

In addition to questions on beliefs, the questionnaire used in this study also included statements designed to gauge learners' attitudes to various aspects of language learning in school. These were selected according to hypotheses about what might impact on learning outcomes. Learners were asked about assessment and grades as it was felt that these play an important role in the Polish school culture. They were also asked to give opinions on their teacher of English and their behavior towards the learning group, as research on school effectiveness (Hattie, 2002) indicates that teacher factors account for some $30 \%$ of the difference between results in different schools. As personal language learning experience can affect current attitudes to learning (see Kalaja et al., 2008) several statements referring to attitudes towards language learning in primary school, where all of those participating had start- 
ed English, were included. Parts of the questionnaire covered learners' opinions about classroom interaction during their English lessons at school with a view to finding out whether learners felt positive about their language lessons. Positive attitudes towards the learning situation have been found to be associated with increased motivation, which in turn can impact on outcomes (Masgoret and Gardner, 2003: 194).

\section{The sample}

The 120 schools were selected randomly from public gimnazja to create a representative sample on a national scale. Each school director in the sample was then asked to select three groups learning English according to the continuation program for English in the core curriculum (Program III.1) where possible representing different levels of ability. As the learning groups within the schools were not selected randomly, this sample cannot be strictly considered as representative. Only learners in class one of lower secondary were included. 344 learning groups took part in the survey, with an average of 12 students per group. The learners' parents or guardians gave written permission for their children to take part in the research. Of the 4716 learners eligible, $92.09 \%$ took part, a total of 4343 . Given the fact that the schools present a representative sample and that groups of different levels of language ability were selected in each school, with appropriate caution generalizations can be made about language learning in class one gimnazjum on the basis of this study.

\section{The research instrument}

As indicated in the introduction, this article describes part of a larger study. The research on learner beliefs and attitudes was conceived within a contextual approach, as outlined above. Data were collected by means of a questionnaire, which is the focus of this report, but also by means of structured interviews, within which selected learners were asked to describe their ideal foreign language lesson. In a second questionnaire information was collected about how learners approach language learning in their own time, through a battery of questions on what they do, how often and how they do it. Finally classes were observed, audio-recorded, transcribed and analyzed. Information presented here should be considered preliminary, as it covers only one of the instruments and that only partially, because of limitations of space. 
Learners completed a pen and paper questionnaire comprising 60 statements in Polish with a five point Likert scale as follows:

$5=$ I totally agree $4=$ I mostly agree $3=\mid$ partly agree and partly disagree

$2=I$ don't really agree $1=I$ totally disagree.

Learners were instructed to circle the number which best reflected their opinion on each statement.

Some of the statements in the questionnaire came from different sources. 11 statements were taken from the BALLI questionnaire (Horwitz ,1987); 4 items were adapted from the English Attitude Motivation Test Battery (AMBT) (Gardner, 2004); 4 items were adapted from a questionnaire prepared for learners in Hungary by Csizer and Kormos (2009) and one item from Taguchi et al. (2009). 5 questions referring to learning foreign language in primary school were taken from a questionnaire designed by the author and used in a study in 2009. The remaining 39 items were written specifically for this project. Items originally in English were translated and then read and edited by two reviewers before being re-translated. The questionnaire was then piloted by the author together with a team of college students in nine lower secondary schools, selected for convenience, with a total of 183 learners. The wording of four of the questions was adjusted following questions from participants. As the questionnaire received interested response from those who took part in the pilot study, it was considered valid. Each of the statements was found to discriminate well, with distribution across the five possible responses.

\section{Research procedure}

The main study was offered for public tender and data collection was conducted by the winning firm under supervision of the Educational Research Institute, Warsaw. As this is a large-scale study which involved a large number of people in the administration of the questionnaire, great care had to be taken to ensure reliability and that all data were collected under similar conditions. Instructions for the team recruited to collect the data were prepared by the researchers and each of the 55 members took part in a training session where an introduction to the project was given and the procedure was explained. Using a prepared script members of the data collection team visited the selected schools, between 12 April and 9 May 2012, where they explained to the selected groups of learners how to complete the pen and paper questionnaire. Each learner was given a code number which was used to identify their questionnaire so that anonymity was assured. Learners 
were also informed that nobody from the school in which the research was conducted would have access to the completed questionnaires. This was felt to be important as some of the questions asked learners to give opinions on their current teachers of English.

Data was entered into a spreadsheet twice by separate coders. A third person then checked the two data bases and any differences found were verified against the original questionnaires and corrections made. The resulting data base was also checked for completeness using the attendance records from each data collection session.

The frequencies for each statement were noted and means and standard deviation calculated.

Some of the questions on the questionnaire were divided into several subscales which were checked for internal consistency using Cronbach's alpha coefficient. The mean reliability coefficient is given in brackets for each of the sub-scales. 0.6 was taken as an acceptable level and 0.8 can be considered good. The sub-scales which will be discussed here are as follows: reflections on learning in primary school (0.84); attitudes to and opinions on learning English in the current class at school (0.8); opinions about assessment in English lessons (0.68) and opinions about the English teacher in school (0.86). These represent only some of the sub-scales.

\section{Findings}

For reasons of space this article will present only selected items from the questionnaire. The first set of statements, taken from BALLI, concerns the nature of foreign language learning. The numbers given are the numbers from the questionnaire. Findings will be represented graphically and then described.

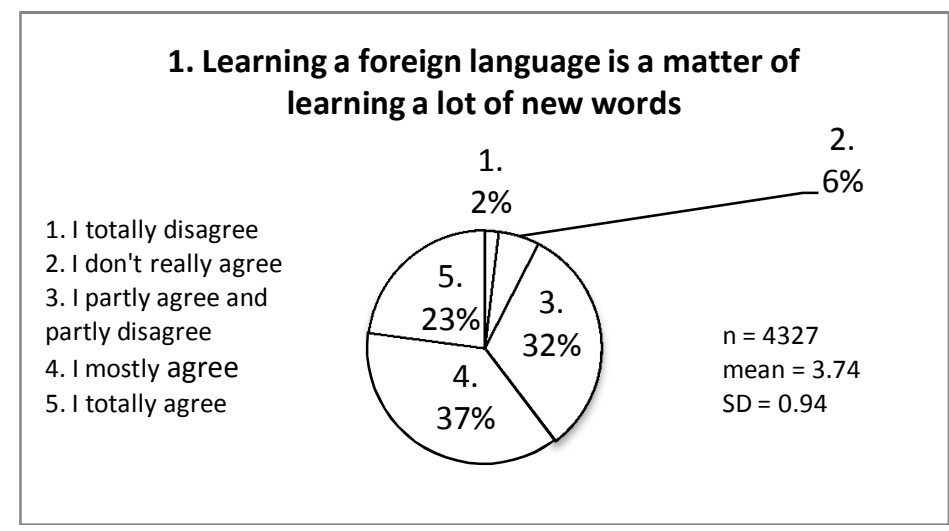

Diagram 1: Learning a foreign language is a matter of learning a lot of new words 
As we can see from Diagram 1, 60\% of the respondents agreed with the statement either totally or mostly, as opposed to $8 \%$ who disagreed. The remainder ( $32 \%$ ) were undecided, choosing "I partly agree and partly disagree". The majority of the group appear to believe that learning words is of key importance to language learning.

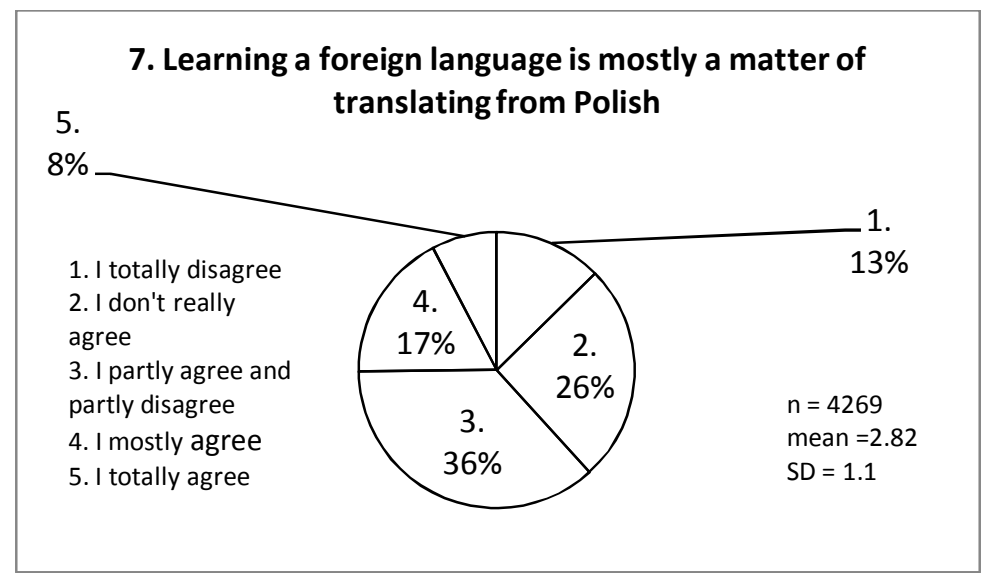

Diagram 2: Learning a foreign language is mostly a matter of translating from Polish.

Diagram 2 above shows that 39\% of the learners do not agree that foreign language learning mainly means translating from Polish. 25\% agree with the statement, while $36 \%$ partly agree and partly disagree. It can be seen that the respondents are strongly divided on this issue.

Below in Diagram 3 we can see that $29 \%$ of learners agree that "Learning grammar is a mostly a matter of learning rules" while $14 \%$ disagree. The majority, $47 \%$, are undecided on this question, a fact which suggests that the sample are more biased towards grammar being important than against it. It can be seen that this distribution is quite different from beliefs on the importance of vocabulary shown in Diagram 1. 


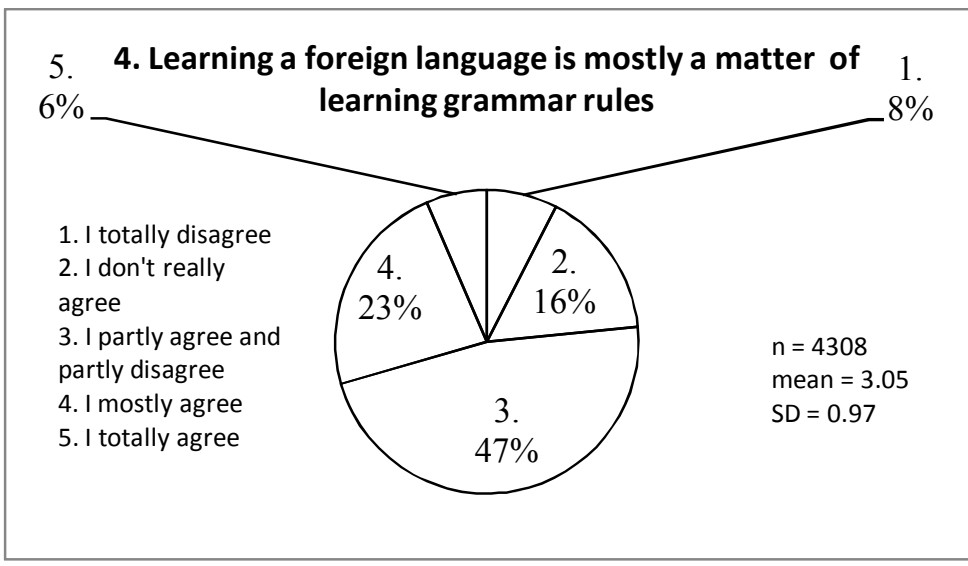

Diagram 3: Learning a foreign language is mostly a matter of learning grammar rules.

The data included in diagram 4 demonstrate that learners believe learning a foreign language is in some way different from learning other school subjects, with $63 \%$ in agreement, while only $15 \%$ disagree.

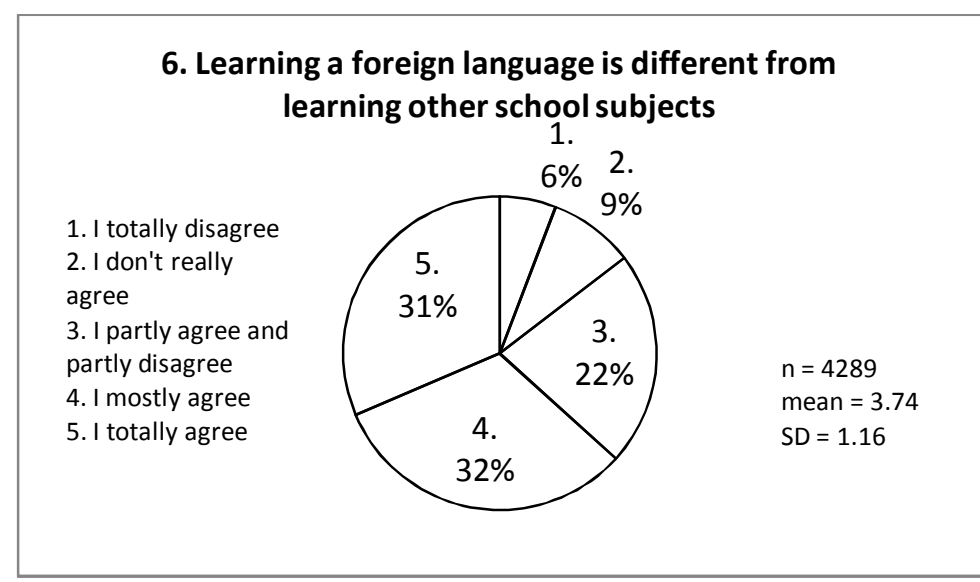

Diagram 4: Learning a foreign language is different from learning other school subjects.

The next set of statements, also taken from BALLI, can be considered to be about the difficulty of learning foreign languages:

The first of these is illustrated in Table 5 below. Somewhat surprisingly 41\% of respondents agree that "It is easier to speak than to understand a foreign language", while $27 \%$ disagree. A similar number, $32 \%$, are undecided. 


\section{It is easier to speak than to understand a foreign language}

1. I totally disagree

2. I don't really agree

3. I partly agree and partly disagree 4. I mostly agree 5. I totally agree

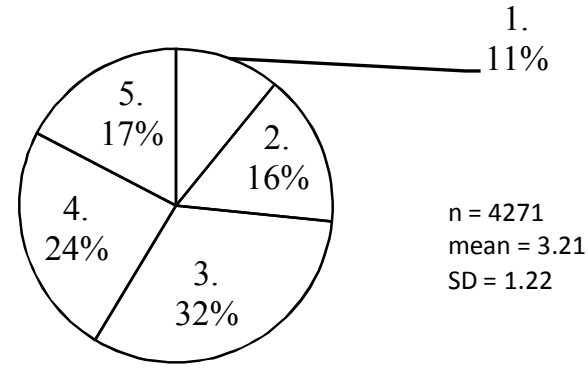

Diagram 5: It is easier to speak than to understand a foreign language.

This result is to some extent confirmed in Diagram 6, where we see that $35 \%$ feel that reading and writing in a foreign language is easier than speaking and understanding; while $32 \%$ disagree. As we saw above that $27 \%$ felt understanding was easier than speaking, it could be expected that a similar number might agree reading is easier. However, as the choice here is for both reading and writing, in other words for both receptive and productive skills, we cannot expect mirrored scores. The lower number agreeing here may suggest that writing is not a skill in which the respondents feel confident.

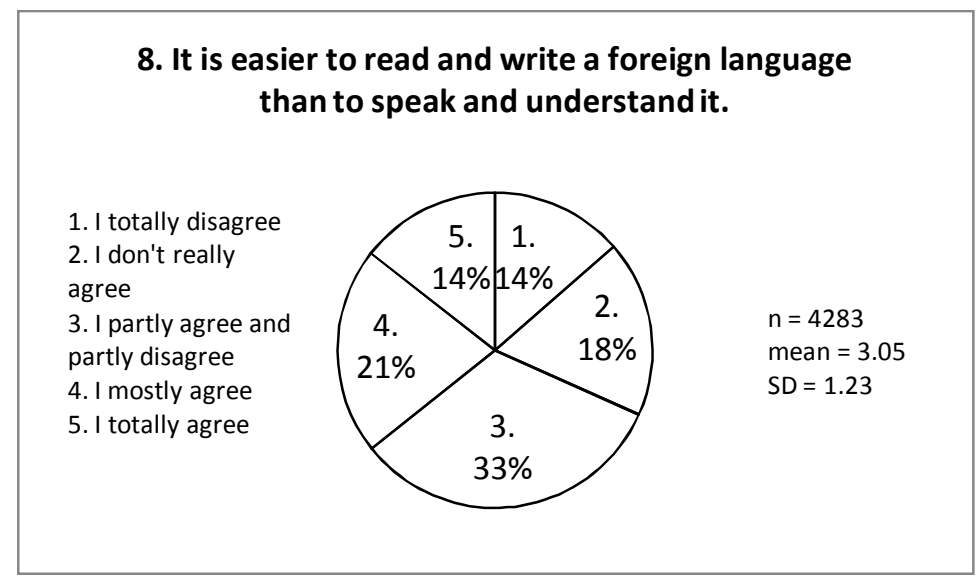

Diagram 6: It is easier to read and write a foreign language than to speak and understand it.

By contrast we can see a strongly positive trend in the next statement, with a clear majority of $82 \%$ agreeing that everyone is able to learn to speak a for- 
eign language. Only $8 \%$ disagree. This suggests favorable attitudes towards foreign language learning, which implicitly suggests foreign language teaching in school may be considered well-received.

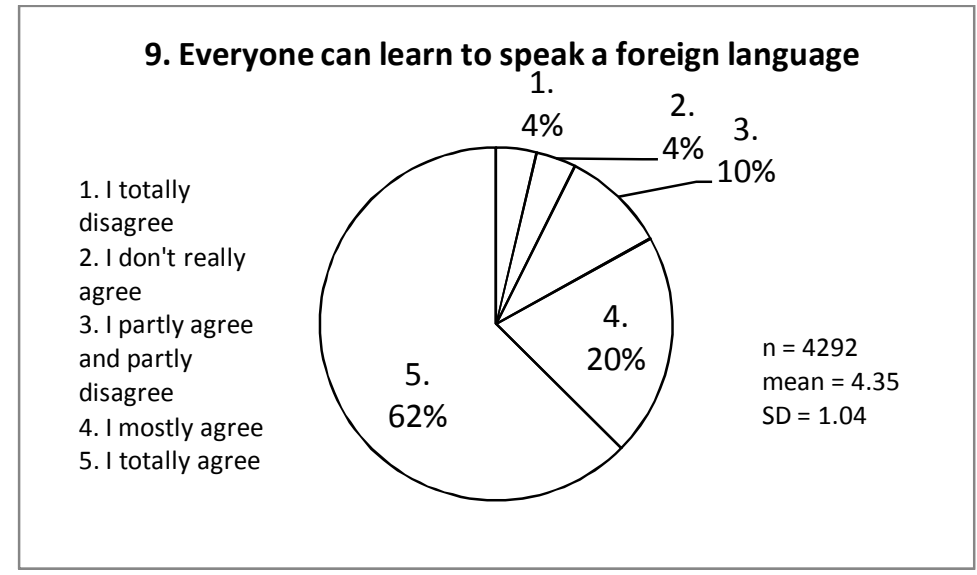

Diagram 7: Everyone can learn to speak a foreign language.

The next set of statements concern strategies for learning and communication. Learners appear to have clear ideas about the amount of effort needed to learn a foreign language as $75 \%$ agree that a lot of repetition and practice are needed with only $8 \%$ disagreeing.

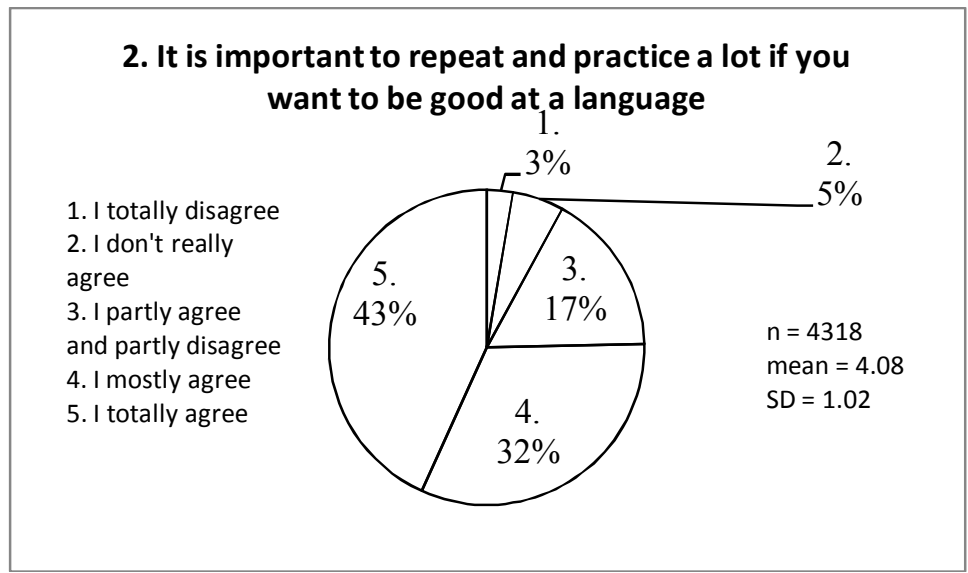

Diagram 8: It is important to repeat and practice a lot if you want to be good at a language.

In Diagram 9 below learners give their views on the role of accuracy in speaking. We can see that learners appear to favor attempting to convey their message even if they make mistakes, as $65 \%$ disagree with the state- 
ment "You shouldn't say anything in the foreign language until you can say it correctly". 12\%, however, appear not to be willing to communicate, as they agree with the statement and a further $23 \%$ are undecided.

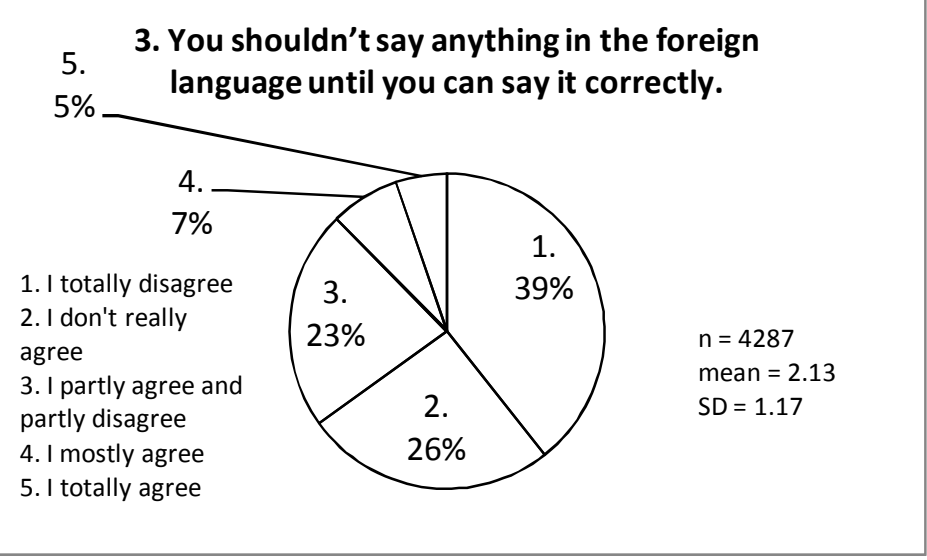

Diagram 9: You shouldn't say anything in the foreign language until you can say it correctly.

These proportions are reflected in Diagram 10 with $69 \%$ declaring that they do not feel self-conscious about speaking a foreign language in front of others, while $16 \%$ appear to be reticent. It seems logical that if making mistakes is not an issue then there will be fewer barriers to speaking out in front of a group.

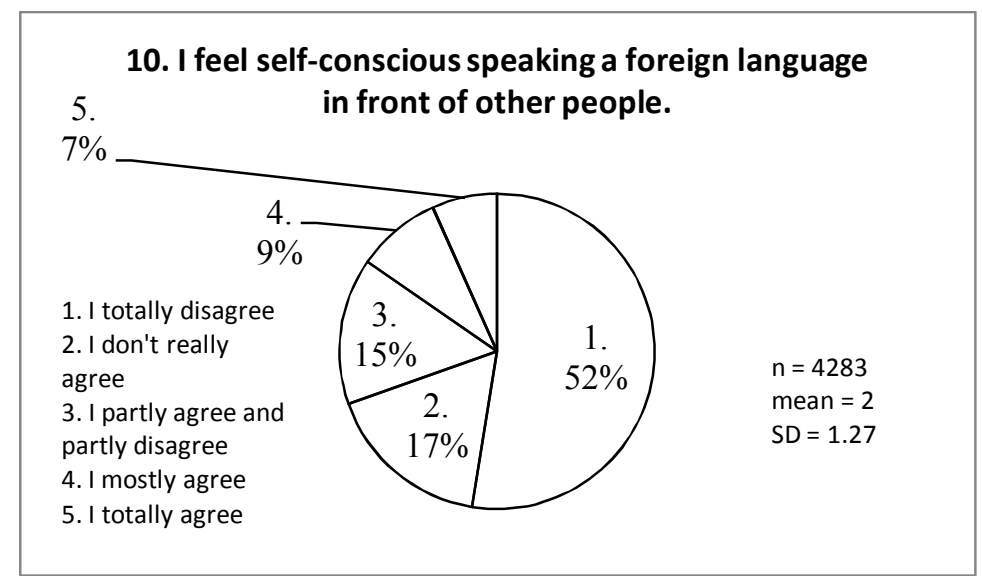

Diagram 10: I feel self-conscious speaking a foreign language in front of other people.

The next set of statements to be described are those from the subscale about the teacher of English in school, shown below in Table 1 . On the whole we can say that the learners appear to feel positive towards their 
teachers. $82.22 \%$ find their teacher enthusiastic in lessons and towards the subject; $77.9 \%$ think their teacher is helpful and friendly and $77.59 \%$ declare that $s /$ he is fair to everyone in the class. Somewhat fewer, but still a majority at $60.67 \%$, say that their English teacher gives them good advice about how to study the language. $15.92 \%$ however, disagree, which is a large enough percentage to suggest that this is an area for teacher development.

\begin{tabular}{|l|l|c|c|c|c|c|c|}
\hline $\begin{array}{l}\text { Question } \\
\text { number }\end{array}$ & $\begin{array}{l}\text { Opinions about teacher } \\
\text { of English in school }\end{array}$ & $\begin{array}{c}1 . \text { I totally } \\
\text { disagree }\end{array}$ & $\begin{array}{c}\text { 2.I don't } \\
\text { really } \\
\text { agree }\end{array}$ & $\begin{array}{c}3 . \text { I partly } \\
\text { agree and } \\
\text { partly disagree }\end{array}$ & $\begin{array}{c}4.1 \\
\text { mostly } \\
\text { agree }\end{array}$ & $\begin{array}{c}5.1 \\
\text { totally } \\
\text { agree }\end{array}$ & $\begin{array}{c}\text { Number } \\
\text { answering } \\
\text { Mean } \\
\text { Standard } \\
\text { deviation }\end{array}$ \\
\hline 35 & $\begin{array}{l}\text { My English teacher is fair } \\
\text { to all the learners }\end{array}$ & 5.88 & 4.77 & 11.82 & 23.62 & 53.97 & $\begin{array}{l}n=4315 \\
m=4.15 \\
\mathrm{SD}=1.16\end{array}$ \\
\hline 36 & $\begin{array}{l}\text { My English teacher is } \\
\text { enthusiastic in lessons } \\
\text { and likes English }\end{array}$ & 2.96 & 3.65 & 1.17 & 25.28 & 56.94 & $\begin{array}{l}\mathrm{n}=4324 \\
\mathrm{~m}=4.3 \\
\mathrm{SD}=1\end{array}$ \\
\hline 37 & $\begin{array}{l}\text { My English teacher is } \\
\text { helpful and friendly }\end{array}$ & 3.78 & 5.68 & 12.91 & 23.41 & 54.49 & $\begin{array}{l}\mathrm{n}=4313 \\
\mathrm{~m}=4.19 \\
\mathrm{SD}=1.1\end{array}$ \\
\hline 38 & $\begin{array}{l}\text { My English teacher gives } \\
\text { me good advice about } \\
\text { how to study English }\end{array}$ & 6.42 & 9.5 & 18.4 & 30.54 & 35.13 & $\begin{array}{l}\mathrm{n}=4316 \\
\mathrm{~m}=3.78 \\
\mathrm{SD}=1.2\end{array}$ \\
\hline
\end{tabular}

Table 1: Opinions about teacher of English in school (in percentages).

The next subscale to be described gives learners' views on assessment and can be seen in Table 2 below. Learners were given four statements regarding the kinds of formative assessment which takes place in their language classes. Tests of grammar and vocabulary were found to be most common, with $58.22 \%$ agreeing that they have these regularly. Next came marks for writing, with $55.38 \%$ agreeing they are regularly graded. Listening and reading came third, with $41.9 \%$ claiming these are tested regularly and finally was speaking, with only $23.49 \%$ stating that this is marked regularly and $44.95 \%$ disagreeing. $65.69 \%$ of the learners felt that their teachers explain requirements for obtaining a given grade, while nearly $16 \%$ claim this does not happen. Generally learners appear positive towards the marks they receive for English, with $66.66 \%$ feeling that they accurately reflect their level. By contrast $12.46 \%$ appear clearly dissatisfied with their marks and $21.27 \%$ are ambivalent. 
Melanie Ellis

\begin{tabular}{|c|c|c|c|c|c|c|c|}
\hline $\begin{array}{l}\text { Question } \\
\text { number }\end{array}$ & Opinions about assessment & $\begin{array}{l}\text { 1. I totally } \\
\text { disagree }\end{array}$ & $\begin{array}{l}2 . \text { Idon't } \\
\text { really } \\
\text { agree }\end{array}$ & $\begin{array}{l}\text { 3. I partly } \\
\text { agree and } \\
\text { partly disa- } \\
\text { gree }\end{array}$ & $\begin{array}{l}4.1 \\
\text { mostly } \\
\text { agree }\end{array}$ & $\begin{array}{l}5.1 \\
\text { totally } \\
\text { agree }\end{array}$ & $\begin{array}{c}\text { Number } \\
\text { answering } \\
\text { Mean } \\
\text { Standard } \\
\text { deviation }\end{array}$ \\
\hline 30 & $\begin{array}{l}\text { We regularly have tests of } \\
\text { grammar or vocabulary }\end{array}$ & 5.4 & 10.8 & 25.57 & 28.06 & 30.16 & $\begin{array}{l}n=4333 \\
m=3.67 \\
S D=1.17\end{array}$ \\
\hline 31 & $\begin{array}{l}\text { We regularly get marks for } \\
\text { speaking }\end{array}$ & 18.36 & 26.59 & 31.55 & 15.8 & 7.69 & $\begin{array}{l}n=4369 \\
m=2.68 \\
S D=1.17\end{array}$ \\
\hline 32 & $\begin{array}{l}\text { We regularly have tests of } \\
\text { listening and reading }\end{array}$ & 10.72 & 18.76 & 28.62 & 23.88 & 18.02 & $\begin{array}{l}\mathrm{n}=4318 \\
\mathrm{~m}=3.2 \\
\mathrm{SD}=1.24\end{array}$ \\
\hline 33 & $\begin{array}{l}\text { We regularly get marks for } \\
\text { writing }\end{array}$ & 6.35 & 12.31 & 25.95 & 28.01 & 27.37 & $\begin{array}{l}n=4312 \\
m=3.58 \\
S D=1.19\end{array}$ \\
\hline 50 & $\begin{array}{l}\text { Our teacher explains what } \\
\text { we have to do to get a } \\
\text { certain mark in English (eg. } \\
3,4,5, \text { etc.) }\end{array}$ & 6.42 & 9.5 & 18.4 & 30.54 & 35.15 & $\begin{array}{l}n=4316 \\
m=3.78 \\
S D=1.2\end{array}$ \\
\hline 60 & $\begin{array}{l}\text { I think the marks I get for } \\
\text { English represent my level } \\
\text { of knowledge }\end{array}$ & 5.78 & 6.68 & 21.27 & 30.24 & 36.02 & $\begin{array}{l}n=4325 \\
m=3.14 \\
S D=1.16\end{array}$ \\
\hline
\end{tabular}

Table 11: Opinions about assessment (in percentages).

The remaining sets of statements were included as they seem to indicate cause for concern. Two of the statements in the set shown in Table 3 below relate to how work in the English lesson is organized. Learners were asked about how frequently they work in small groups and in pairs. Less than half of the sample (42.92\%) consider that they often work in pairs, while $28.96 \%$ disagree with the statement. This raises questions about the amount of practice being afforded during English lessons if half the sample appear to work much of the time in lockstep. Small group work is even less frequent with only $28.11 \%$ agreeing that this often occurs and $44.46 \%$ disagreeing. One possible reason for the low incidence of group work may be the age group in question, as young teenagers can be challenging to manage, which may account for the apparent infrequency. It is less clear why pair work also appears unpopular.

The final statement in the set refers to learners' opinions about language lessons. $26.74 \%$ think that most of their lessons are spent learning grammar while $17.73 \%$ disagree. The majority, 55.53\%, partly agree and partly disagree. In all, it appears that learning grammar, at least in the view of a large percentage of the respondents, takes up a substantial part of lesson time. 
Beliefs and attitudes about language learning and teaching among learners...

When we remember that grammar is a small part of the content of the core curriculum this is worrying.

\begin{tabular}{|c|c|c|c|c|c|c|c|}
\hline $\begin{array}{c}\text { Question } \\
\text { number }\end{array}$ & Causes for concern & \begin{tabular}{|c|}
1.1 \\
totally \\
disagree
\end{tabular} & $\begin{array}{l}\text { 2. Idon't } \\
\text { really } \\
\text { agree }\end{array}$ & $\begin{array}{l}\text { 3. I partly agree } \\
\text { and partly } \\
\text { disagree }\end{array}$ & $\begin{array}{l}4.1 \\
\text { mostly } \\
\text { agree }\end{array}$ & $\begin{array}{l}5.1 \\
\text { totally } \\
\text { agree }\end{array}$ & $\begin{array}{c}\text { Number } \\
\text { answering } \\
\text { Mean } \\
\text { Standard } \\
\text { deviation }\end{array}$ \\
\hline 48 & $\begin{array}{l}\text { We often work together in } \\
\text { small groups in English } \\
\text { lessons }\end{array}$ & 19.88 & 24.58 & 27.44 & 17.44 & 10.67 & $\begin{array}{l}n=4301 \\
m=2.74 \\
S D=1.26\end{array}$ \\
\hline 47 & $\begin{array}{l}\text { We often work in pairs } \\
\text { during English lessons }\end{array}$ & 11.23 & 17.73 & 28.12 & 23.37 & 19.55 & $\begin{array}{l}\mathrm{n}=4292 \\
\mathrm{~m}=3.22 \\
\mathrm{SD}=1.26\end{array}$ \\
\hline 27 & $\begin{array}{l}\text { Most of our lessons are } \\
\text { spent learning grammar }\end{array}$ & 3.95 & 13.78 & 55.53 & 20.96 & 5.78 & $\begin{array}{l}n=4375 \\
m=3.11 \\
S D=0.85\end{array}$ \\
\hline
\end{tabular}

Table 12: Causes for concern (in percentages).

The next set of statements refer to learners who can be considered to be 'at risk' and are shown in Table 14 below. At first sight, the percentages may mislead, with a majority of $54.21 \%$ disagreeing with the statement "It doesn't matter to anyone if I learn foreign languages or not". However $20.14 \%$ agree, indicating a lack of support and encouragement for a disturbingly large percentage of learners. An additional $25.56 \%$ are undecided, which also suggests a degree of uncertainty about the level of positive reinforcement they are receiving. As lack of support from family or friends can negatively impact on motivation, this is an area which needs to be addressed in schools, where teachers can give positive feedback and help learners to feel valued.

\begin{tabular}{|l|l|c|c|c|c|c|c|}
\hline $\begin{array}{l}\text { Question } \\
\text { number }\end{array}$ & \multicolumn{1}{|c|}{ Learners 'at risk' } & $\begin{array}{c}1 . \text { I totally } \\
\text { disagree }\end{array}$ & $\begin{array}{c}2 . \text { I don't } \\
\text { really } \\
\text { agree }\end{array}$ & $\begin{array}{c}3.1 \text { partly } \\
\text { agree and } \\
\text { partly disagree }\end{array}$ & $\begin{array}{c}4.1 \\
\text { mostly } \\
\text { agree }\end{array}$ & $\begin{array}{c}5.1 \\
\text { totally } \\
\text { agree }\end{array}$ & $\begin{array}{c}\text { Number } \\
\text { answering } \\
\text { Mean } \\
\text { Standard } \\
\text { deviation }\end{array}$ \\
\hline 55 & $\begin{array}{l}\text { It doesn't matter to any- } \\
\text { one if I learn foreign } \\
\text { languages or not }\end{array}$ & 31.52 & 22.69 & 25.65 & 11.21 & 8.93 & $\begin{array}{l}n=4280 \\
m=2.43 \\
S D=1.28\end{array}$ \\
\hline 54 & $\begin{array}{l}\text { Everyone around me } \\
\text { thinks that learning } \\
\text { foreign languages is a } \\
\text { waste of time }\end{array}$ & 32.46 & 28.66 & 23.84 & 8.69 & 6.34 & $\begin{array}{l}n=4291 \\
m=2.28 \\
S D=1.19\end{array}$ \\
\hline
\end{tabular}

Table 13: Learners 'at risk' (in percentages). 
The final set of statements were included to promote further reflection on what foreign language lessons are really like, for just over $20 \%$ of this sample claim that they are boring, and almost $16 \%$ feel they do not get much chance to speak, while $26.08 \%$ claim that their teacher corrects them every time they say something in English.

\begin{tabular}{|l|l|c|c|c|c|c|c|}
\hline $\begin{array}{l}\text { Question } \\
\text { number }\end{array}$ & For reflection & $\begin{array}{c}1 . \text { I totally } \\
\text { disagree }\end{array}$ & $\begin{array}{c}2 . \text { I don't } \\
\text { really } \\
\text { agree }\end{array}$ & $\begin{array}{c}3.1 \text { partly } \\
\text { agree and } \\
\text { partly disa- } \\
\text { gree }\end{array}$ & $\begin{array}{c}4.1 \\
\text { mostly } \\
\text { agree }\end{array}$ & $\begin{array}{c}5.1 \\
\text { totally } \\
\text { agree }\end{array}$ & $\begin{array}{c}\text { Number } \\
\text { answering } \\
\text { Mean } \\
\text { Standard } \\
\text { deviation }\end{array}$ \\
\hline 25 & $\begin{array}{l}\text { English lessons in } \\
\text { school are boring }\end{array}$ & 32.2 & 25.5 & 22.11 & 11.32 & 8.86 & $\begin{array}{l}n=4310 \\
m=2.39 \\
\text { SD }=1.28\end{array}$ \\
\hline 28 & $\begin{array}{l}\text { We do not get much } \\
\text { opportunity to speak } \\
\text { during English lessons }\end{array}$ & 35.42 & 28.7 & 20.09 & 9.65 & 6.13 & $\begin{array}{l}n=4320 \\
m=2.22 \\
\text { SD }=1.2\end{array}$ \\
\hline $\begin{array}{l}\text { The teacher corrects } \\
\text { me every time I say } \\
\text { something in English }\end{array}$ & 16.62 & 27.31 & 29.98 & 14.10 & 11.98 & $\begin{array}{l}n=4339 \\
m=2.78 \\
\text { SD }=1.23\end{array}$ \\
\hline
\end{tabular}

Table 14: For reflection (in percentages).

\section{Discussion}

Statements adopted from BALLI were included here to allow comparison with studies in other countries. However, this must be done with caution, as these other studies did not always include learners from a similar age group, or learning situation. Horwitz (1999: 565), when overviewing studies in Taiwan, Korea and Turkey conducted using BALLI, found that "all groups of EFL students agreed that the most important part of learning a language was learning vocabulary words (agreement ranging from 42 to $79 \%$ )", so the fact that Polish learners would also agree was to be expected. Similarly, it was found that all groups reviewed by Horwitz considered learning a foreign language different from other subjects, a fact also mirrored in the Polish study. Beliefs about grammar, as found here, were divided in other studies, with most disagreeing that language learning is mostly a matter of learning grammar rules (ranging from 29-81\%). However, learners in Turkey were found to strongly agree on the importance of grammar $(72-80 \%)$, while Taiwanese and particularly Korean students were against, a reaction, Horwitz suggests, to a focus on grammar in the syllabus (ibid.) Thus, this might suggest that learners in the Polish context may also be reacting negatively to a focus on grammar, but clearly further evidence is needed before this can be stated with any conviction. As far as the importance of 
translation in language learning is concerned, Horwitz found differences between groups where different languages were being studied, with students of German and Spanish agreeing on the saliency of translation by up to $70 \%$, while a majority (65\%) of students of French disagreed. With EFL students percentages were noticeably lower, particularly among Korean and Taiwanese, although two studies in Korea obtained results of different magnitude on this item. In one of the Korean studies 38\% agreed with the statement, showing a distribution which bears some resemblance to the Polish results. In all contexts results divided the samples, suggesting that this issue is subject to considerable individual difference and may also be affected by the learning culture, materials and teaching methodology. In sum, the Polish results on beliefs about the nature of foreign language learning can be said to be in keeping with other studies in different contexts and among different types of learners.

More difficult to interpret are the two statements referring to beliefs about the difficulty of language skills, where the Polish learners were positive towards "It is easier to speak than to understand a foreign language", with $41 \%$ agreeing. In the recently conducted European Survey on Language Competences (ESLC) (2011), Polish learners did rather poorly on tests of reading and listening, with approximately $60 \%$ scoring below curriculum targets of level A2 on the Common European Framework ( ESLC 2012). By contrast, in a study of spoken competence conducted on some of the same learners in Poland, only $41 \%$ did not achieve level A2 on the speaking test, suggesting that results on speaking are in fact better than the understanding of texts. In this context the learners' response could be seen to indicate an accurate understanding by the learners of their language abilities in the different skill areas. In the ESLC it was on the test of writing that learners in Poland scored best of the three subtests, with approximately $45 \%$ on target for curriculum standards (ESLC 2012), a fact that may be reflected in the fact that $35 \%$ of the sample thought reading and writing were easier than speaking and understanding. However, as a very similar number (32\%) disagreed, this interpretation is hard to justify.

An alternative interpretation may be the influence of prevalent ways in which the foreign language is assessed in class. We saw that learners claim they receive grades for writing and that they have tests of grammar and vocabulary more frequently than tests of listening and reading. By contrast, grades for speaking are received less frequently. We also saw that learners do not appear to be reticent about trying to speak, or to have concerns about making mistakes. This would suggest that attitudes towards speaking appear to be positive and that as it is less frequently tested learners may 
have a more optimistic opinion of their ability in speaking than in the other skills, where they are regularly graded. Obviously further investigation is needed to discover the source of learners' beliefs on this topic. It is to be hoped that triangulation with other data in the larger BUNJO study will throw more light on this.

Teachers of English, both those remembered from previous language learning experiences and those currently teaching these learners, are seen in a very positive light, as in the main are lessons of English. However, as described above, it is curious that when the national core curriculum places emphasis on being able to use the foreign language in order to communicate learners claim that work in pairs is not an everyday occurrence and that work in groups is a rarity. We are left wondering how practice in communication takes place in many of the classrooms where these learners study. Is it that learners ask and answer questions in open pairs, while the rest of the class listen? Or is the partner in the communication usually the teacher? Or are communicative activities being done in writing, through interaction with text-based exercises? Or perhaps learners are not fully aware of how work in their language lessons is organized and in fact pair work is more frequent than we are led to believe? And yet approximately $16 \%$ state clearly that they feel they do not have enough opportunity to speak and a further $20 \%$ partially agree with this, which seems to suggest that part of the learners in the study would prefer to be more actively engaged and that it may be that an increase in the number of activities in pairs may be the answer. It is hoped that data from the classroom observation part of BUNJO will be able to answer some of these questions, as lessons attended by these same learners were observed.

Running through the responses we can find that there appear to be a small group, of perhaps between $12-15 \%$, who seem less positive about language learning in general. It will be interesting to trace whether these are learners with lower results in foreign languages and possibly also in Polish. Is it that difficulty with language learning causes less positive beliefs, or is it that these results are simply part of a more complex picture? ESLC found that where parents were thought by their children to be good at foreign languages this was associated with the young people getting better results. Is the fact that around $20 \%$ here claim that nobody cares whether they learn foreign languages or not a message about lack of parental ability or interest in foreign languages? If this is found to be the case, it would seem to suggest that there is a need for increased outreach work on the part of schools to work with the families of their pupils and also for more to be done in school to persuade learners that their efforts are valued. As teachers of English have been found to be highly regarded by their learners this strategy has a chance to succeed. 


\section{Conclusions}

To conclude, this questionnaire study can be said to present a positive picture of foreign language learning and teaching, and in particular a positive approach towards the teaching and learning of English, among these learners from class one gimnazjum (lower secondary school) in Poland. Learners appear to carry with them good memories of foreign language learning from primary school, which suggests that this pattern of satisfaction is not specific to only one stage of education. While there are indications of some areas for improvement, such as an increased variety in how lessons are organized, attitudes towards their current language learning situation in school are also positive among learners in the sample. This is a preliminary report on a small part of a complex data set and it is hoped that several of the questions raised by the findings will be able to answered through triangulation with other data in the wider study.

\section{Acknowledgements}

This research was financed by the European Union under the European Social Fund - Operational Programme Human Capital, Priority III - High quality of education; within the grant "Quality and effectiveness of education - strengthening of institutional research capabilities" Section 3.1.1 Creating conditions and tools for monitoring, evaluating and researching the educational system.

This study would not have been possible without the help of a large number of people, who include: Katarzyna Paczuska and Dominika Chandler for translation and editing of the questionnaire; Anna Michałowska and Katarzyna Kulas for work on preparation of data collector training materials and conducting the training session; Students from the diploma seminar group at NKJO Zabrze for conducting the pilot study in 2011.

\section{BIBLIOGRAFIA}

Abraham, R. and Vann, R. 1987. "Strategies of two language learners: A case study". In A. Wenden and J. Rubin (Eds.), Learner strategies in language learning Englewood Cliffs, N.J.: Prentice Hall: 85-102.

Barcelos, A. M. F. 1995. A cultura aprender lingua estrangiera (inglěs) de alunos de letras (The culture of learning a foreign language (English) of language students.) Unpublished master's thesis. UNICAMP, São Paulo, Brazil. 
Barcelos, A. M. F. 2003. "Researching beliefs about SLA: A critical review." In P. Kalaja and A. M. F. Barcelos (Eds.), Beliefs about SLA: New research approaches. Dordrecht: Kluwer Academic Publishers: 7-33.

Csizer, K. and Kormos, J. 2009. "Learning experiences, selves and motivated learning behavior: a comparative analysis of structural models of Hungarian secondary and university learners of English." In Dörnyei, Z. and Ushioda, E. (eds.) Motivation, Language Identity and the L2 Self. Bristol: Multilingual Matters: 98-119.

Ellis, R. 2008. "Learner beliefs and language learning". Asian EFL Journal, Vol. 10, No. 4: Conference Proceedings: 7-25.

European Survey on Language Competences 2012. First European Survey on Language Competences. Final Report. European Commission Education and Training.

Flavell, J.H. 1987. "Speculation about the nature and development of metacognition". In F.E. Weinert, \& R.H. Kluwe, (Eds.), Metacognition, motivation and understanding. Hillsdale, NJ: Lawrence Erlbaum: 1-29.

Gardner, R. C. 1985. Social Psychology and Second Language Learning: The Role of Attitudes and Motivation. London: Edward Arnold.

Gardner, R. C. 2004. Attitude Motivation Test Battery. International AMTB Research Project. Downloaded from http://publish.uwo.ca/ gardner/docs/englishamtb.pdf on 4.09.2012.

Gardner, R. C. 2006. "The socio-educational model of second language acquisition: a research paradigm." In Foster-Cohen, S.H., Medved Krajnović, M. and Mihaljević Djigunović, J. (eds.), EUROSLA Yearbook Vol. 6. Amsterdam: John Benjamins: 237-260.

Hattie, J.A C. 2002. "What are the attributes of excellent teachers?" In Teachers make a difference: What is the research evidence? Wellington: New Zealand Council for Educational Research: 3-26.

Horwitz, E.K. 1987. "Surveying student beliefs about language teaming". In A.L.

Wenden \& J. Robin (Eds.), Learner strategies in language learning. London: Prentice Hall: 119-132.

Horwitz, E.K. 1999. "Cultural and situational influences on foreign language learners' beliefs about language learning: A Review of BALLI Studies." [Special Issue]. System, 27: 557-576.

Kalaja, P., Menezes, V. \& Barcelos, A-M. (Eds.) 2008. Narratives of learning and teaching EFL. Basingstoke: Palgrave Macmillan.

Masgoret, A-M. and Gardner, R. 2003. "Attitudes, Motivation, and Second Language

Learning: A Meta-Analysis of Studies conducted by Gardner and Associates". In Dörnyei, Z. (ed.) Attitudes, Orientations, and Motivations in Language Learning: Advances in Theory, Research and Applications. Oxford: Blackwell: 167- 210.

Mori, Y. 1999. "Epistemological beliefs and language learning beliefs: What do language learners believe about their learning". Language Learning, 49: 377-415.

Park, G. P. 1995. Language learning strategies and beliefs about language learning of university students learning English in Korea. Unpublished Doctoral Dissertation. The University of Texas at Austin, TX. 
Beliefs and attitudes about language learning and teaching among learners...

Ryan, M.P. 1984. "Monitoring text comprehension: Individual differences in epistemological standards". Journal of Educational Psychology, 76 (2): 248-258.

Taguchi, T., Magid, M. and Papi, M. 2009. "The L2 motivational self system among Japanese, Chinese and Iranian learners of English: A comparative study". In Dörnyei, Z. and Ushioda, E. (eds.) Motivation, Language Identity and the L2 Self. Bristol: Multilingual Matters: 66-97.

Tanaka, K. and Ellis, R. 2003. "Study abroad, language proficiency, and learner beliefs about language learning". JALT Journal, 25: 63-85.

Victori, M. \& Lockhart, W. 1995. "Enhancing metacognition in self-directed language learning". System, 23(2): 223-234.

Wenden, A. 1986. "What do second language learners know about their language learning? A second look at retrospective accounts". Applied Linguistics, 7: 186-201.

Wenden, A. 1999. An introduction to metacognitive knowledge and beliefs in language learning: Beyond the basics [Special Issue]. System, 27: 435-441. 